\title{
Petrogenetic relationship between mafic magma of somma lavas and voluminous felsic magma with caldera formation: A case study of Akan volcanic field, eastern Hokkaido, Japan
}

\author{
Yasuo IKEDA \\ Department of Earth Science, Hokkaido University of \\ Education at Kushiro, Kushiro 085-8580, Japan
}

\begin{abstract}
Volcanic activity in the Akan volcanic field in the southwestern end of the Kurile arc began in early Pleistocene and formed stratovolcanoes. The somma lavas are tholeiite series and range from 51-60 wt\% $\mathrm{SiO}_{2}$. The eruption of voluminous calc-alkali rhyolitic magma (68-73 wt\% $\left.\mathrm{SiO}_{2}\right)$ with caldera formation took place at middle Pleistocene. The trace-element characteristics of the volcanic rocks from the Akan volcanic field suggest that the felsic magma implies a difficulty for its derivation from basaltic magma such as the somma lava. Modeling the trace element processes in volcanic rocks indicate that the most basic rock of the somma plots near partial melting $20 \%$ of the mantle source with the fractional crystallization subsequent to the partial melting. On the other hand, the Akan pyroclastic flow deposits may be produced by variable degree of partial melting of an andesitic crust source with local heterogeneity of the source material. The most plausible heat source for the genesis of the felsic magma may be latent heat from the mantle-derived basaltic magma such as the somma lava.
\end{abstract}

\section{Introduction}

It is well known that mantle-derived basalt magmas at the deep crust are inevitably associated with the anatexis of the crustal rocks (e.g. Hildreth, 1981; Takahashi et al., 1997). Some Japanese Quaternary volcanoes are characterized by activity of basaltic magmas of somma and voluminous rhyolitic magma with caldera formation. The volcanic activities at the subduction zone are expected the formation of felsic magmas by latent heat from the mantle-derived basalt magmas (e.g. Hildreth, 1981; Wada, 1989; Ikeda, 1991; Takahashi et al., 1997). This petrogenetic relationship is of particular importance to discuss about the magma-feeding system in subduction zone.

The Akan volcanic field is composed of precaldera stratovolcano (somma) and the Akan caldera formed after the voluminous eruption of pyroclastic flow and the deposition of pyroclastic fall (Satoh, 1965). Some data of major elements for the volcanic rocks are presented in Satoh (1965) and Wada (1989). Trace element

Y. Ikeda, ikeda@kus.hokkyodai.ac.jp Corresponding author studies became a vital part of modern petrology and more capable to discriminate petrological processes than that on the major elements alone (Rollinson, 1993). This report is presented the geochemical information including major and trace elements of the Akan magmas and discussed the petrogenetic relationship between mafic magma of somma lavas and voluminous felsic magma.

\section{Geological setting}

The Akan volcanic field in eastern Hokkaido (Fig. 1) is located at the southwestern end of the Akan-Shiretoko volcanic chain, belonging to the Kurile volcanic zone. Paleogene- and Neogene-Tertiary basement rocks (sedimentary and volcanic rocks) exist underneath the volcanic field (Satoh, 1965). The stratovolcanoes in the volcanic field is distinct on the NW and SE walls, composed of piles of somma lavas and pyroclastic rocks of basaltic-andesitic compositions (Satoh, 1965) (Fig. 1). The volcanic formation has been presumed early Pleistocene in age (Katsui and Koide, 1976). K-Ar age on a somma lava indicates Pliocene age (2.82 Ma; NEDO, 

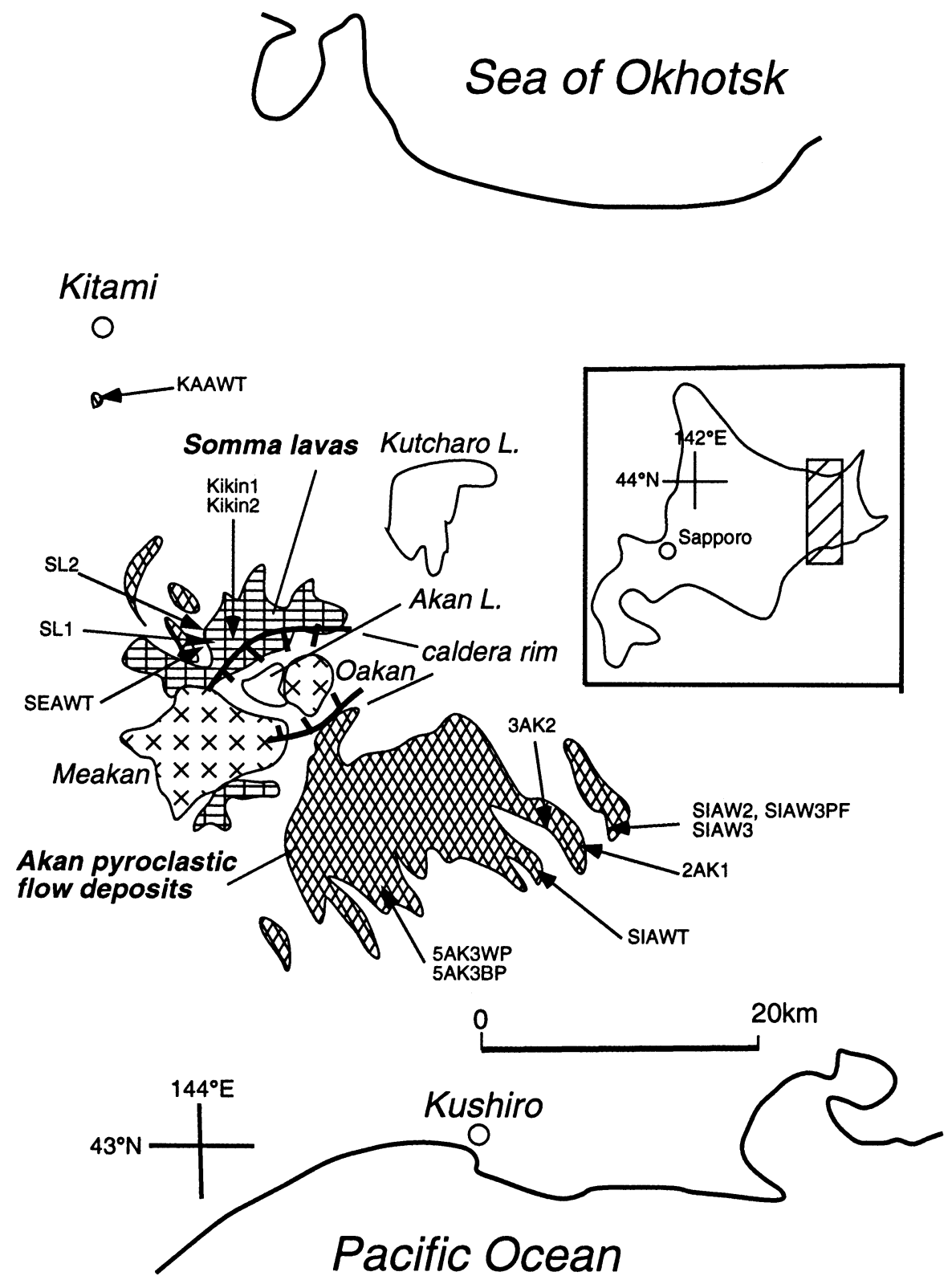

Figure 1. Distribution of somma lavas, Akan pyroclastic flow deposits and post caldera stratovolcanoes; Meakan including Furebetsu and Fuppusi, and Oakan (modified from Geological Survey of Hokkaido, 1980), and locations of caldera rim (simplified from Satoh, 1965) and analyzed samples in the Akan volcanic field.

1992). After the formation of stratovolcanoes, eruption of voluminous pyroclastic flows and pumice falls (Akan pyroclastic flow deposits) were succeeded. The Akan caldera was formed in middle Pleistocene (Satoh, 1965; Okazaki, 1966; Satoh and Sato, 1976) (Fig. 1). The volume of the Akan pyroclastic flow deposit is estimated to be about $100 \mathrm{~km}^{3}$ (Ishikawa et al., 1969), and mass deficiency calculation on the caldera is $165 \mathrm{~km}^{3}$ (Ohkawa and Yokoyama, 1979). K-Ar ages on the two samples of Akan pyroclastic flow deposits have been dated as 0.59 and 2.2 Ma (NEDO, 1992). The isotopic ages of the pyroclastic flow deposits are not necessarily in agreement with the stratigraphic age (middle Pleistocene). The Akan caldera is rectangular shape (ca. 20 $\mathrm{km}$ in $\mathrm{E}-\mathrm{W}$ diameter) and the gravity anomalies show inverted cone (Ohkawa and Yokoyama, 1979). Four post caldera staratovolcanoes; Furebetsu, Fuppusi, Meakan (included in Meakan in Fig. 1), and Oakan, have grown in the caldera or the caldera-rim since late Pleistocene (Satoh, 1965).

\section{Samples and analytical methods}

Sample localities are shown in Figure 1. Phenocrysts of somma lavas for SL1 and SL2 are plagioclase, olivine and small amount of clinopyroxene lie in an intergranular matrix of plagioclase, clinopyroxene and iron mineral. The somma lavas for Kikin 1 and Kikin 2 are aphyric and a little plagioclase phenocrysts are embedded in an intergranular groundmass of plagioclase, 
clinopyroxene and iron mineral. The commonest phenocrysts of Akan pyroclastic flow deposits are plagioclase followed in the order of abundance by orthopyroxene and clinopyroxene.

Concentrations of major elements and trace elements $(\mathrm{Rb}, \mathrm{Sr}, \mathrm{Ba}, \mathrm{Nb}, \mathrm{Y}, \mathrm{Zn}$ and $\mathrm{Zr}$ ) were determined by XRF (X-ray fluorescence Rigaku RIX 3000) at National Institute of Polar Research, Tokyo. Analytical procedures of Motoyoshi and Shiraishi (1995) were used.

Other trace elements (Hf, Ta, Th, and $\mathrm{U}$ ) and REE ( $\mathrm{La}, \mathrm{Ce}, \mathrm{Sm}, \mathrm{Eu}, \mathrm{Tb}, \mathrm{Yb}$ and $\mathrm{Lu}$ ) were analyzed by instrumental neutron activation analysis (INAA) at the Institute for Atomic Energy, Rikkyo University, Yokosuka. Samples of $\sim 200 \mathrm{mg}$ were doubly packed into precleaned polyethylene bags and irradiated for $12 \mathrm{~h}$ in a TRIGA MARK II $(100 \mathrm{kw})$ research reacter facility. The irradiated samples were left standing for about one week to cool the radioactivities of the short-lived nuclides such as $\mathrm{La}, \mathrm{Sm}, \mathrm{Yb}$, and $\mathrm{Lu}$. The cooling time was about four weeks for long-lived nuclides such as $\mathrm{Ce}$, $\mathrm{Eu}$ and $\mathrm{Tb}$. After the suitable cooling time, $\gamma$-ray spectrometry was carried out with a Ge detector. The analytical uncertainties for most samples were estimated to be about $\pm 10 \%$, but $\mathrm{Ta}$ and $\mathrm{Tb}$ for some samples were $\pm 15-20 \%$.

\section{Geochemical characteristics}

The major and trace element compositions of the volcanic rocks are given in Tables 1 and 2. The volcanic rocks are grouped on the basis of $\mathrm{SiO}_{2}$ content into basalt (45-53\%), basaltic andesite (53-57\%), andesite (57 $-63 \%)$, dacite (63-68\%), and rhyolite $(>68 \%)$ after the proposition by Basaltic Volcanism Study Project (1981). The somma lavas are basalt for SL1 and SL2 $\left(51 \% \mathrm{SiO}_{2}\right)$ and basaltic andesite to andesite for Kikin 1 and Kikin $2\left(55-60 \% \mathrm{SiO}_{2}\right)$. The range of $\mathrm{SiO}_{2}$ contents for somma lavas are in general agreement with the data given by Wada (1989). The Akan pyroclastic flow deposits are rhyolite $\left(68-73 \% \mathrm{SiO}_{2}\right)$. Most of the volcanic rocks of the Akan volcanic field are subdivided into Medium-K type (Le Maitre et al., 1989) on the basis of $\mathrm{K}_{2} \mathrm{O}$ vs. $\mathrm{SiO}_{2}$ diagram (Fig. 2). The different trend of tholeiite rock series and calc-alkali rock series can be used to $\mathrm{SiO}_{2}$ vs. $\mathrm{FeO} * \mathrm{MgO}$ diagram (Miyashiro, 1974). The somma lavas and the Akan pyroclastic flow deposits belong to the tholeiite rock and to the calcalkali rock series, respectively (Fig. 3).

$\mathrm{Rb}, \mathrm{Sr}$ and $\mathrm{Ba}$ vs. $\mathrm{SiO}_{2}$ diagrams for the volcanic rocks from the Akan Volcanic field is shown in Figure 4. $\mathrm{Rb}$ and $\mathrm{Ba}$ contents of the somma lavas increase
Table 1. Major element abundances (wt\%) in the volcanic rocks from the Akan volcanic field

\begin{tabular}{lrrrr}
\hline & \multicolumn{4}{c}{ Somma lavas } \\
\cline { 2 - 5 } & $\mathrm{SL1}$ & \multicolumn{1}{c}{ SL2 } & Kikin1 & Kikin2 \\
\hline $\mathrm{SiO}_{2}$ & 51.28 & 51.42 & 55.06 & 60.23 \\
$\mathrm{TiO}_{2}$ & 0.77 & 0.78 & 1.12 & 0.95 \\
$\mathrm{Al}_{2} \mathrm{O}_{3}$ & 17.97 & 17.76 & 16.19 & 15.97 \\
$\mathrm{Fe}_{2} \mathrm{O}_{3}{ }^{*}$ & 10.25 & 10.31 & 11.97 & 9.70 \\
$\mathrm{MnO}$ & 0.17 & 0.17 & 0.22 & 0.16 \\
$\mathrm{MgO}$ & 5.85 & 5.83 & 3.43 & 2.18 \\
$\mathrm{CaO}$ & 11.02 & 11.02 & 7.57 & 6.23 \\
$\mathrm{Na}{ }_{2} \mathrm{O}$ & 2.01 & 2.09 & 3.42 & 3.71 \\
$\mathrm{~K}_{2} \mathrm{O}$ & 0.43 & 0.47 & 0.81 & 1.34 \\
$\mathrm{P}_{2} \mathrm{O}_{5}$ & 0.06 & 0.06 & 0.19 & 0.23 \\
\hline Total & 99.81 & 99.91 & 99.98 & 100.70 \\
\hline
\end{tabular}

$\mathrm{Fe}_{2} \mathrm{O}_{3}{ }^{*}$ : total iron as $\mathrm{Fe}_{2} \mathrm{O}_{3}$

Table 2. Trace elementabundances (ppm) in the volcanic rocks from the Akan volcanic field

\begin{tabular}{crrrr}
\hline & \multicolumn{4}{c}{ Somma lavas } \\
\cline { 2 - 5 } & SL1 & \multicolumn{1}{c}{ SL2 } & Kikin1 & Kikin2 \\
\hline $\mathrm{Rb}$ & 9.79 & 12.02 & 15.43 & 29.62 \\
$\mathrm{Sr}$ & 358.15 & 355.93 & 386.18 & 350.61 \\
$\mathrm{Ba}$ & 93.55 & 89.06 & 195.73 & 312.46 \\
$\mathrm{Nb}$ & 2.50 & 1.82 & 4.69 & 4.69 \\
$\mathrm{Y}$ & 15.48 & 15.62 & 27.72 & 36.06 \\
$\mathrm{Zn}$ & 69.06 & 68.97 & 99.68 & 93.99 \\
$\mathrm{Zr}$ & 52.12 & 55.03 & 81.87 & 117.67 \\
$\mathrm{La}$ & 5.17 & 3.95 & 9.54 & 14.50 \\
$\mathrm{Ce}$ & 8.89 & 8.05 & 18.75 & 26.02 \\
$\mathrm{Sm}$ & 2.20 & 2.34 & 3.87 & 5.88 \\
$\mathrm{Eu}$ & 0.80 & 0.72 & 1.39 & 1.64 \\
$\mathrm{~Tb}$ & 0.50 & 0.49 & 0.85 & 0.75 \\
$\mathrm{Yb}$ & 1.74 & 1.31 & 2.74 & 3.45 \\
$\mathrm{Lu}$ & 0.27 & 0.27 & 0.41 & 0.55 \\
$\mathrm{Hf}$ & 1.02 & 1.43 & 2.32 & 2.95 \\
$\mathrm{Ta}$ & 0.41 & 0.35 & 0.55 & 0.69 \\
$\mathrm{Th}$ & 0.57 & 0.75 & 1.18 & 2.11 \\
$\mathrm{U}$ & 0.53 & 0.33 & 0.35 & 0.80 \\
\hline & & & &
\end{tabular}


Table 1. continued

\begin{tabular}{lrrrrrrrrrr}
\hline & \multicolumn{10}{c}{ Akan pyroclastic flow deposits } \\
\cline { 2 - 11 } & SEAWT & KAAWT & \multicolumn{10}{c}{ SIAWT } & 2AK1 & 3AK2 & 5AK3WP & 5AK3BP & SIAW2 & SIAW3PF & SIAW3 \\
\hline $\mathrm{SiO}_{2}$ & 72.43 & 72.93 & 72.38 & 70.70 & 72.92 & 70.89 & 68.62 & 71.91 & 71.73 & 71.54 \\
$\mathrm{TiO}_{2}$ & 0.54 & 0.51 & 0.52 & 0.48 & 0.51 & 0.49 & 0.59 & 0.56 & 0.46 & 0.43 \\
$\mathrm{Al}_{2} \mathrm{O}_{3}$ & 13.37 & 13.36 & 13.88 & 15.13 & 13.50 & 13.58 & 14.39 & 14.68 & 13.94 & 13.89 \\
$\mathrm{Fe}_{2} \mathrm{O}_{3}{ }^{*}$ & 3.08 & 2.73 & 2.71 & 3.21 & 2.53 & 3.60 & 4.55 & 2.88 & 3.03 & 3.07 \\
$\mathrm{MnO}$ & 0.11 & 0.13 & 0.13 & 0.09 & 0.12 & 0.08 & 0.10 & 0.14 & 0.10 & 0.09 \\
$\mathrm{MgO}$ & 0.64 & 0.71 & 0.73 & 0.85 & 0.67 & 0.95 & 1.20 & 0.74 & 0.80 & 0.86 \\
$\mathrm{CaO}$ & 2.38 & 2.43 & 2.55 & 2.96 & 2.46 & 3.09 & 3.60 & 2.60 & 2.75 & 3.06 \\
$\mathrm{Na}{ }_{2} \mathrm{O}$ & 4.15 & 4.46 & 4.54 & 3.88 & 4.56 & 3.75 & 3.54 & 4.41 & 3.92 & 4.07 \\
$\mathrm{~K}_{2} \mathrm{O}$ & 1.99 & 1.66 & 1.56 & 1.77 & 1.65 & 2.26 & 2.00 & 1.50 & 1.94 & 1.94 \\
$\mathrm{P}_{2} \mathrm{O}_{5}$ & 0.06 & 0.08 & 0.08 & 0.07 & 0.08 & 0.05 & 0.08 & 0.08 & 0.06 & 0.06 \\
\hline Total & 98.75 & 99.00 & 99.08 & 99.14 & 99.00 & 98.74 & 98.67 & 99.50 & 98.73 & 99.01 \\
\hline
\end{tabular}

Table 2. continued

\begin{tabular}{|c|c|c|c|c|c|c|c|c|c|c|}
\hline & \multicolumn{9}{|c|}{ Akan pyroclastic flow deposits } & \multirow[b]{2}{*}{ SIAW3 } \\
\hline & SEAWT & KAAWT & SIAWT & $2 \mathrm{AK} 1$ & $3 \mathrm{AK} 2$ & 5AK3WP & $5 \mathrm{AK} 3 \mathrm{BP}$ & SIAW2 & SIAW3PF & \\
\hline $\mathrm{Rb}$ & 48.21 & 35.62 & 34.40 & 39.92 & 34.72 & 59.88 & 53.38 & 33.02 & 44.62 & 43.97 \\
\hline $\mathrm{Sr}$ & 193.24 & 204.93 & 218.26 & 200.09 & 209.90 & 202.27 & 230.49 & 219.50 & 190.71 & 205.51 \\
\hline $\mathrm{Ba}$ & 361.97 & 384.62 & 392.23 & 378.61 & 366.90 & 343.25 & 319.88 & 362.57 & 429.42 & 377.69 \\
\hline $\mathrm{Nb}$ & 4.67 & 2.89 & 3.53 & 3.97 & 4.22 & 5.12 & 4.85 & 3.86 & 4.64 & 3.25 \\
\hline $\mathrm{Y}$ & 43.16 & 40.94 & 42.41 & 31.79 & 40.06 & 33.90 & 33.01 & 43.46 & 30.82 & 28.40 \\
\hline $\mathrm{Zn}$ & 65.08 & 72.61 & 76.79 & 45.37 & 62.06 & 45.96 & 54.55 & 74.02 & 49.72 & 46.45 \\
\hline $\mathrm{Zr}$ & 150.49 & 142.26 & 143.94 & 163.61 & 143.44 & 164.79 & 151.85 & 151.03 & 160.02 & 147.36 \\
\hline $\mathrm{La}$ & 13.14 & 14.28 & 15.35 & 14.13 & 13.36 & 11.50 & 11.51 & 13.93 & 13.99 & 13.71 \\
\hline $\mathrm{Ce}$ & 29.32 & 30.62 & 32.05 & 36.55 & 36.38 & 30.44 & 25.97 & 36.89 & 35.81 & 33.01 \\
\hline $\mathrm{Sm}$ & 5.71 & 5.40 & 5.60 & 4.17 & 5.47 & 4.33 & 4.56 & 5.51 & 4.17 & 4.01 \\
\hline $\mathrm{Eu}$ & 1.31 & 1.46 & 1.48 & 1.08 & 1.51 & 0.93 & 1.16 & 1.68 & 1.04 & 1.00 \\
\hline $\mathrm{Tb}$ & 1.03 & 1.17 & 1.22 & 0.54 & 1.07 & 0.68 & 1.02 & 1.00 & 0.73 & 0.57 \\
\hline $\mathrm{Yb}$ & 4.34 & 3.93 & 4.27 & 3.55 & 4.57 & 3.67 & 4.04 & 4.45 & 3.26 & 3.09 \\
\hline $\mathrm{Lu}$ & 0.72 & 0.69 & 0.72 & 0.54 & 0.62 & 0.53 & 0.56 & 0.61 & 0.54 & 0.50 \\
\hline $\mathrm{Hf}$ & 4.24 & 4.18 & 4.53 & 4.53 & 4.13 & 4.60 & 4.55 & 4.41 & 4.41 & 4.03 \\
\hline $\mathrm{Ta}$ & 0.43 & 0.21 & 0.32 & 0.23 & 0.18 & 0.20 & 0.24 & 0.15 & 0.23 & 0.23 \\
\hline Th & 3.70 & 3.98 & 3.93 & 5.63 & 4.12 & 4.47 & 4.04 & 4.29 & 5.39 & 5.00 \\
\hline $\mathrm{U}$ & 1.36 & 1.13 & 0.88 & 1.60 & 1.26 & 1.39 & 1.41 & 1.16 & 1.63 & 1.30 \\
\hline
\end{tabular}




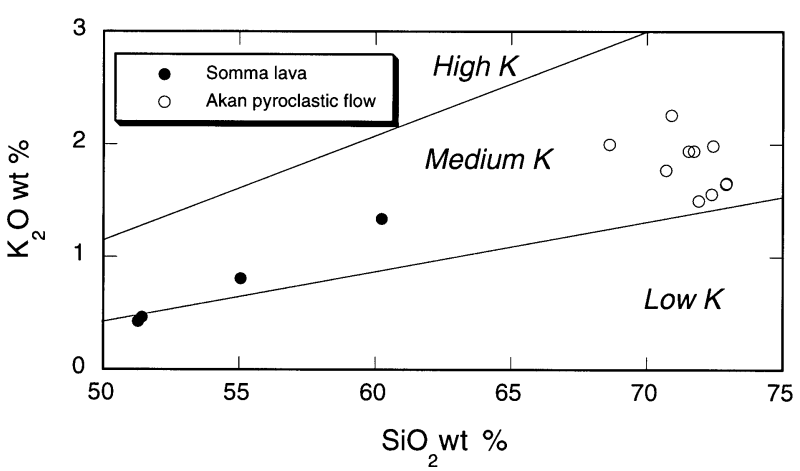

Figure 2. $\mathrm{K}_{2} \mathrm{O}$ vs. $\mathrm{SiO}_{2}$ diagram for the volcanic rocks from the Akan volcanic field. Boundaries among the rock suite fields are after Le Maitre et al. (1989).

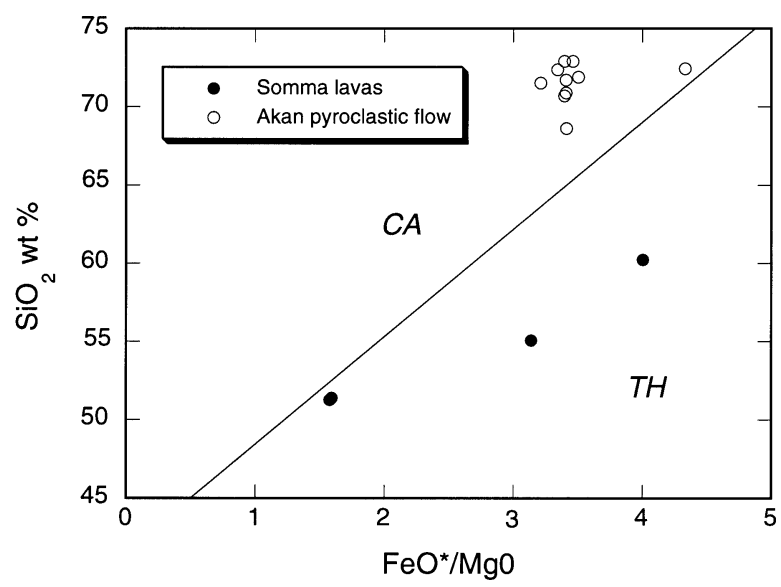

Figure 3. $\mathrm{SiO}_{2}$ vs. $\mathrm{FeO}^{*} / \mathrm{MgO}$ diagram for the volcanic rocks from the Akan volcanic field. $\mathrm{FeO}^{*}$ is total iron as FeO. Solid line defines tholeiitic (TH) and calc-alkalic (CA) series, following Miyashiro (1974).

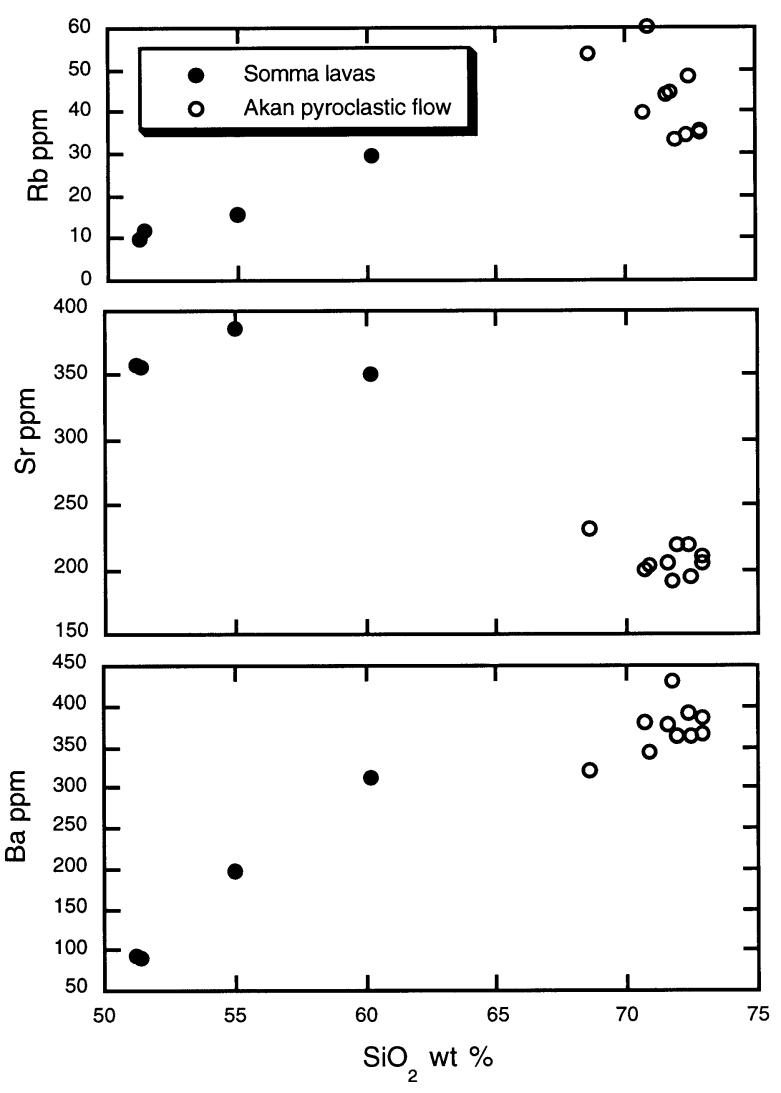

Figure 4. $\mathrm{Rb}, \mathrm{Sr}$ and $\mathrm{Ba}$ vs. $\mathrm{SiO}_{2}$ diagram for the volcanic rocks from the Akan volcanic field.

with increasing $\mathrm{SiO}_{2}$ content, while variation trend of $\mathrm{Sr}$ change to decreasing at fractionated somma lava, indicating the role of plagioclase as fractionating phase. $\mathrm{Sr}$ contents of the Akan pyroclastic flow deposits show also negative correlations. $\mathrm{Rb}$ contents of the pyroclastic flow deposits are plotted in scattered pattern. As shown in $\mathrm{Ba}$ vs. $\mathrm{SiO}_{2}$ diagram, the somma lavas and the pyroclastic flow deposits show independent variation trend.

$\mathrm{Rb}$ vs. $\mathrm{Sr}$ and $\mathrm{Ba}$ vs. $\mathrm{Sr}$ diagrams show more definite
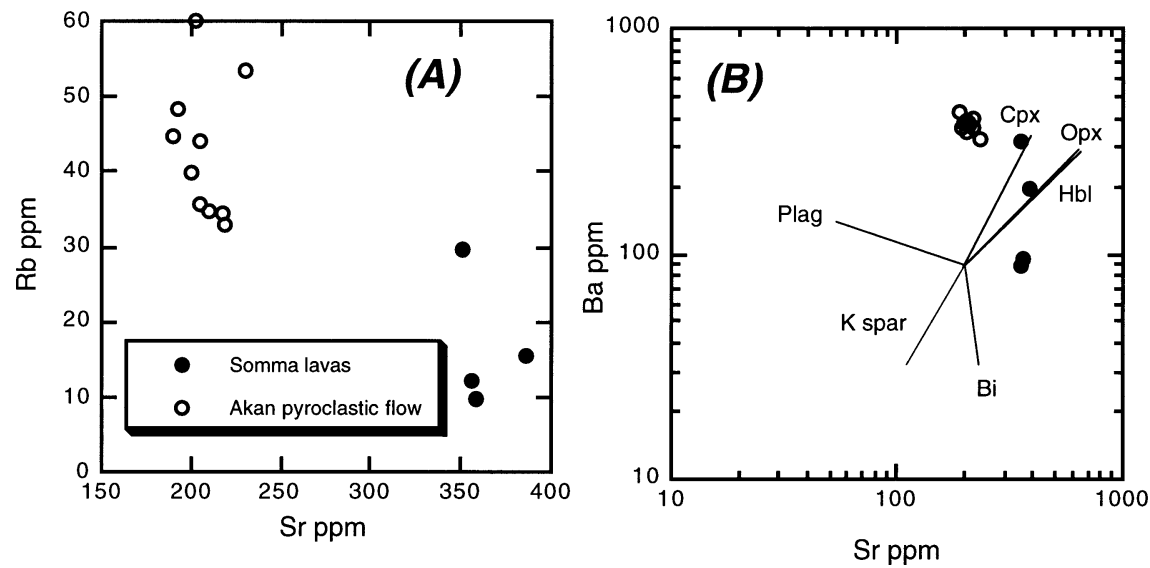

Figure 5. (A) $\mathrm{Rb}$ vs. $\mathrm{Sr}$ and (B) Ba vs. Sr showing fractional crystallization of mineral vector diagrams for the volcanic rocks from the Akan volcanic field. The fractionation vectors are shown for clinopyroxene (Cpx), orthopyroxene (Opx), hornblende ( $\mathrm{Hbl}$ ), biotite $(\mathrm{Bi})$, orthoclase (Kspar) and plagioclase (Plag) after Rollinson (1993). 


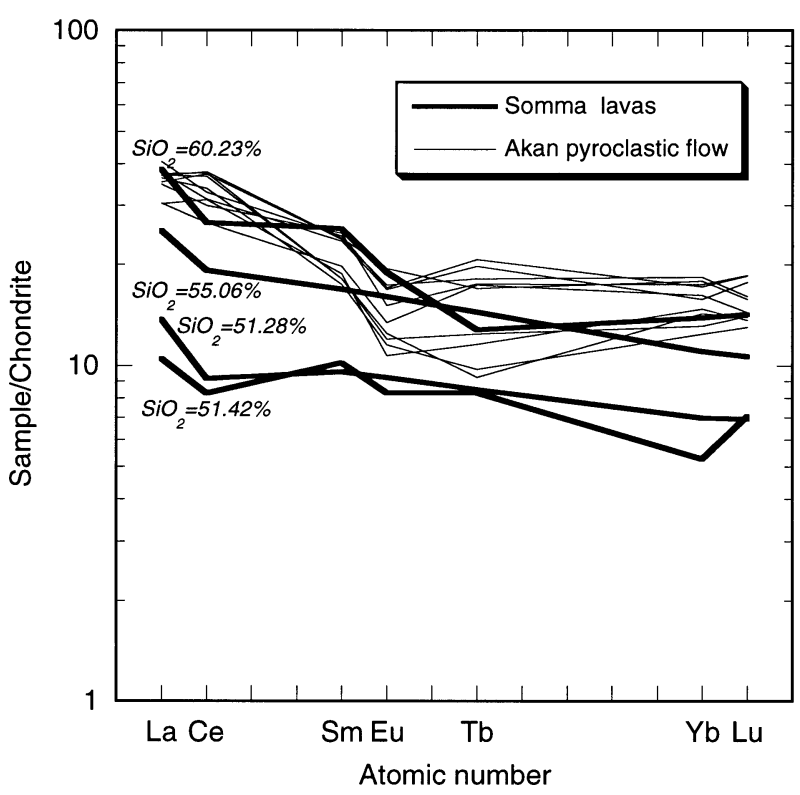

Figure 6. Rare earth element abundances in the volcanic rocks from the Akan volcanic field, normalized to chondritic values after Masuda et al. (1973) and Masuda (1975).

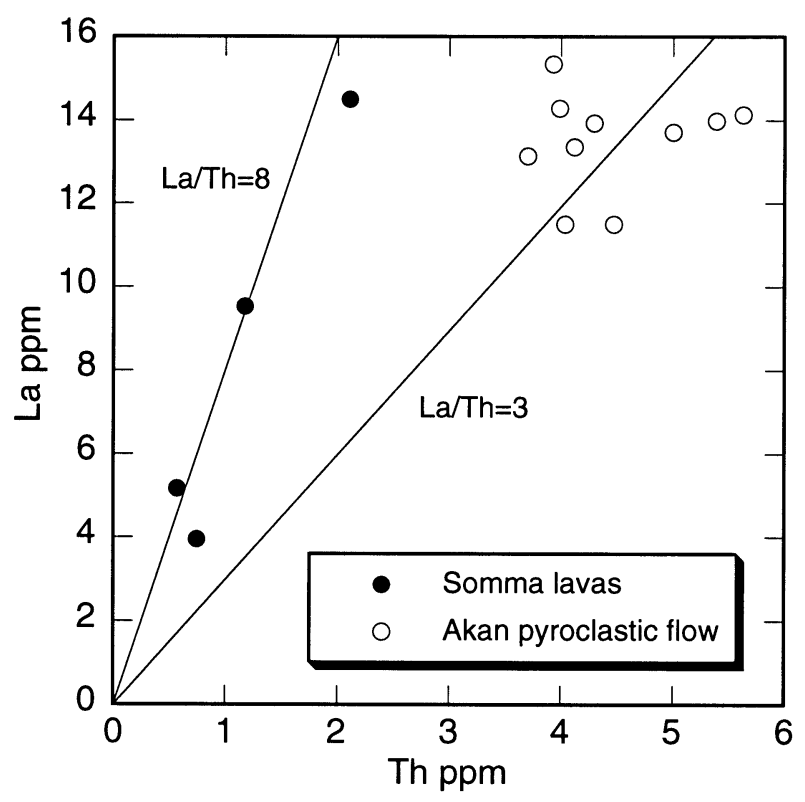

Figure 7. La vs. Th diagram (Gill, 1981) for the volcanic rocks from the Akan volcanic field.

non-genetic relationship between them (Fig. 5). The $\mathrm{Ba}$ vs $\mathrm{Sr}$ diagram of the somma lavas indicates apparently the fractionation of pyroxene and plagioclase as the controlling factor of compositional variation. These trace elements indicate that the Akan pyroclastic flow deposits cannot be derived from the basaltic magma of the somma lava through simple fractional crystallization.

The REE pattern of the somma lavas are light REE (LREE) enriched, while the heavy REE (HREE) parts
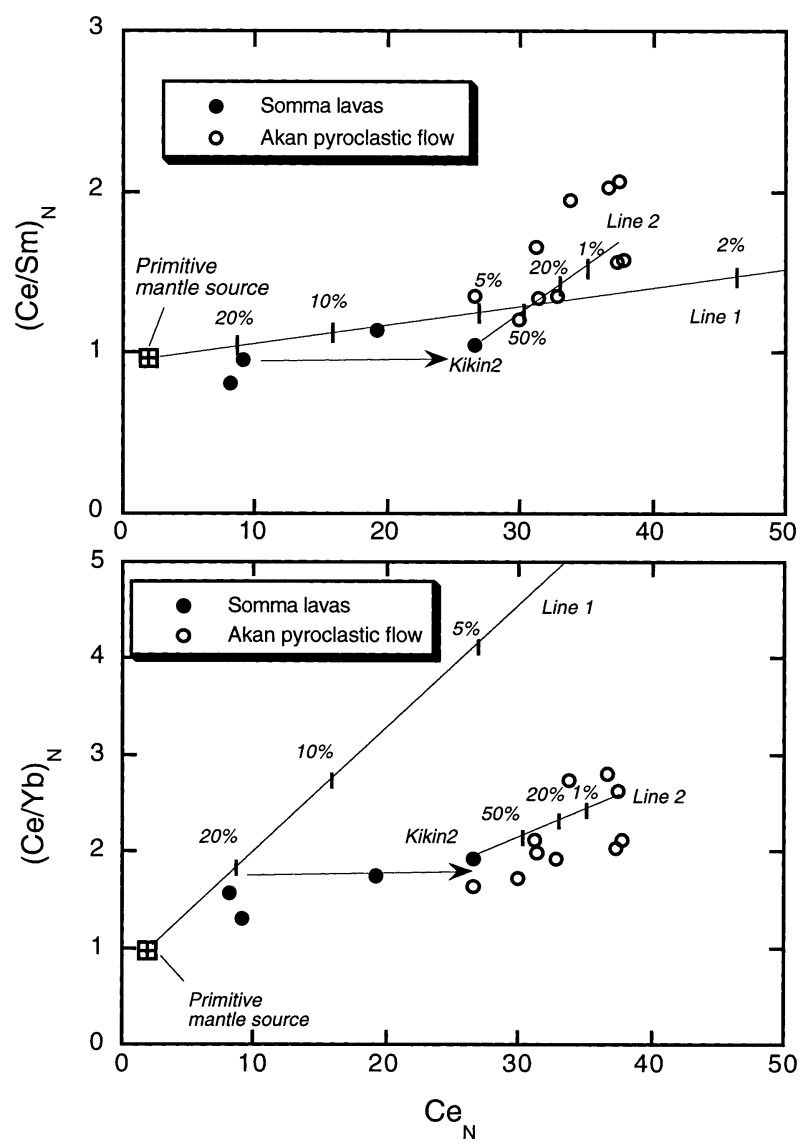

Figure 8. Normalized $(\mathrm{Ce} / \mathrm{Sm})$ vs $\mathrm{Ce}$ and $(\mathrm{Ce} / \mathrm{Yb})$ vs. $\mathrm{Ce}$ diagrams for the volcanic rocks from the Akan volcanic field. The normalizing values and primitive mantle source take from Masuda et al. (1973) and Rollinson (1993), respectively. Mineral/melt partition coefficients compiled from compilation data of Rollinson (1993). Line 1 indicates primitive mantle (olivine: orthopyroxene : clinopyroxene $=60: 27: 13$ ) fusion, assuming partition coefficients $\mathrm{D}_{\mathrm{Ce}} / \mathrm{D}_{\mathrm{Sm}} / \mathrm{D}_{\mathrm{Yb}}$ of $0.006 / 0.007 / 0.049,0$. $02 / 0.05 / 0.34$, and $0.092 / 0.445 / 0.542$ for olivine, orthopyroxene, and clinopyroxene, respectively. Line 2 indicates partial melts of a crust, assuming initial composition Kikin2 (CIPW norm quartz: K-feldspar:plagioclase: clinopyroxene : orthopyroxene : magnetite : ilmenite : apatite $=13.36: 7.93: 54.46: 5.48: 15.02: 1.41: 1.81:$ 0.53 ), and assuming partition coefficients $\mathrm{D}_{\mathrm{Ce}} / \mathrm{D}_{\mathrm{Sm}} / \mathrm{D}_{\mathrm{Yb}}$ of $0.014 / 0.014 / 0.017,0.037 / 0.025 / 0.03,0.267 / 0.165 / 0.09$, $1.833 / 5.233 / 6.367,0.93 / 1.6 / 2.2,3 / 2.2 / 1.8,7.8 / 6.9 / 4.1$, and $34.7 / 62.8 / 23.9$ for quartz, $\mathrm{K}$-feldspar, plagioclase, clinopyroxene, orthopyroxene, magnetite, ilmenite, and apatite, respectively. Numbered tickmarks indicate percent melting. The horizontal allow shows effect of fractional crystallization.

show depleted or flat profile with no Eu anomalies (Fig. 6). The REE abundances of the somma lavas are a type of REE enrichment with the increase of $\mathrm{SiO}_{2}$. The fractionation of REE may be caused by their incompatibility with plagioclase, olivine, and clinopyroxene during the magma evolution. On the other hand, the 
LREE variation patterns of the Akan pyroclastic flow deposits are steep and the HREE parts are flat or slightly enriched compared to middle REE such as Tb profile with negative $\mathrm{Eu}$ anomalies (Fig. 6). Generally, the negative Eu anomalies are mainly controlled by removal of feldspar from a magma or partial melting of a rock in which feldspar retained in the source. The REE patterns of the fractionated somma lavas overlap with those of the Akan pyroclastic flow deposits. The REE patterns indicate that the pyroclastic flow deposit is not likely to have been derived from the basaltic magma of the somma lava by fractional crystallization of plagioclase and pyroxene as well as observed in the trace element data (Figs. 4 and 5).

\section{Petrogenetic relationship between the somma lavas and the felsic rocks}

The geochemical characteristics of the volcanic rocks from the Akan volcanic field indicate a difficulty to derive the felsic magma (Akan pyroclastic flow deposit) from basaltic magma (somma lava).

Ratios of highly incompatible trace elements are indicative of source compositions because they do not change appreciably during either melting or fractionations (Gill, 1981). Consequently, the low $\mathrm{La} / \mathrm{Th}$ ratios of the Akan pyroclastic flow deposits shows a significant difference of their sources from those of the somma lavas (Fig. 7). Further constraints to distinguish the magma processes during fractional crystallization from that of the partial melting can be obtained from vector diagram such as $(\mathrm{Ce} / \mathrm{Yb})$ vs. $\mathrm{Ce}$ and $(\mathrm{Ce} /$ $\mathrm{Sm}$ ) vs. Ce concentrations (Allègre and Minster, 1978; Gill, 1981; Rollinson, 1993). Figure 8 (Ce/Sm vs. Ce and $\mathrm{Ce} / \mathrm{Yb}$ vs. $\mathrm{Ce}$ ) illustrates this difference. Data of primitive mantle source (olivine $60 \%$, orthopyroxene $27 \%$ and clinopyroxene 13\%) and partition coefficients for basaltic liquids for the calculation of batch melting were compiled from Rollinson (1993). The data of the most basic rock of the somma lavas plot near partial melting $20 \%$ of the mantle source. Variations of the data plot of the somma lavas show horizontal variation indicating effect of fractional crystallization.

On the other hand, the data plot for the Akan pyroclastic flow deposits cross the partial melting line or variation trend of the somma lavas. Line 2 in Figure 8 shows compositions of partial melts of andesitic crust, assuming initial composition Kikin $2\left(\mathrm{SiO}_{2}=60.23 \%\right)$ with the CIPW norm mineralogy: quartz (13.36\%), plagioclase (54.46\%), $\mathrm{K}$-feldspar (7.93\%), orthopyroxene (15.02\%), clinopyroxene (5.48\%), magnetite (1.41\%), ilmenite (1.81\%) and apatite (0.53\%). Data of partition coefficients for dacitic and rhyolitic liquids used in the calculation of the partial melting are compiled from Rollinson (1993). The straight line with steep slope on such diagram identifies partial melting (batch melting). The compositional variations of the Akan pyroclastic flow deposits are concordant with the straight line. It indicates that the Akan pyroclatic flow deposits are derived from an andesitic crust source. The variety in composition of the Akan pyroclastic flow deposits may be produced by variable degree of partial melting of the crustal rock and local heterogeneity of the source material. The most plausible heat source for the genesis of the felsic magma may be latent heat from the mantlederived basaltic magma such as the somma lava as discussed in Hildreth (1981), Wada (1989), Ikeda (1991), and Takahashi et al. (1997).

\section{Acknowledgements}

I am grateful to Prof. K. Shiraishi of National Institute of Polar Research for help with XRF analyses. I would like to thank Dr. J. Maeda of Hokkaido University for his advice during INAA work, Dr. S. Miyasaka of IP Co. Ltd. for his assistance during field work, and Dr. K. Wada of Hokkaido University of Education for help with search for references. I also thank two anonymous reviewers for their constructive comments on this manuscript.

\section{References}

Allègre, C.J. and Minster, J.F. (1978) Quantitative models of trace element behavior in magmatic processes. Earth and Planetary Science Letters, 38, 1-25.

Basaltic Volcanism Study Project (1981) Basaltic Volcanism on the Terrestrial Planets. pp. 1286, Pergamon Press Inc, New York.

Geological Survey of Hokkaido (1980) Geological map of Hokkaido, 1:600,000. Geological Survey of Hokkaido, Sapporo.

Gill, J. (1981) Orogenic Andesites and Plate Tectonics. pp. 385, Springer-Verlag, Berlin.

Hildreth, W. (1981) Gradients in silicic magma chamber: implications for lithospheric magmatism. Journal of Geophysical Research, 86, 10153-10192.

Ikeda, Y. (1991) Geochemistry and magmatic evolution of Pliocene-early Pleistocene pyroclastic flow deposits in central Hokkaido, Japan. Journal of Geological Society of Japan, 97, 645-666.

Ishikawa, T., Katsui, Y., Oba, Y. and Sato, H. (1969) Some problems of the calderas in Hokkaido. Bulletin of Volcanological Society of Japan, 14, 97-108 (in Japanese with English abstract).

Katsui, Y. and Koide, K. (1976) Geology and topography of 
the Mt. Meakandake. In Meakandake (Yokoyama, I. et al, Eds.). Committee for Prevention of Disaster of Hokkaido, 3-20 (in Japanese).

Le Maitre, R. W., Bateman, P., Dubek, A., Keller, J., Lameyre, J., Le Bas, M.J., Sabine, P.A., Schmid, R., Sorensen, H., Streckeisen, A., Woolley, A.R. and Zanettin, B. (1989) A classification of igneous rocks and glossary of terms: Recommendations of the international union of geological sciences subcommission on the systematics of igneous rocks. pp. 193, Blackwell Scientific Publications, Oxford.

Masuda, A. (1975) Abundances of monoisotopic REE, consistent with the Leedey chondrite values. Geochemical Journal, 9, 183-184.

Masuda, A., Nakamura, N. and Tanaka, T. (1973) Fine structures of mutually normalized rare earth patterns of chondrites. Geochimica et Cosmochimica Acta, 37, 239248.

Miyashiro, A. (1974) Volcanic rock series in island arc and active continental margins. American Journal of Science, 274, 321-355.

Motoyoshi, Y. and Shiraishi K. (1995) Quantitative chemical analyses of rocks with $\mathrm{X}$-ray fluorescence analyzer: (1) Major elements. Nankyoku Shiryo (Antarctic Record), National Institute of Polar Research, 39, 40-48. (in Japanese with English abstract).

NEDO (1992). Report of Geothermal development promotion survey, Akan area., 26. pp. 440, New Energy and Industrial Technology Development Organization (in Japanese).
Ohkawa, S. and Yokoyama I. (1979) Subsurface structure of Akan caldera based on gravity anomalies. Geophysical Bulletin of Hokkaido University, 38, 17-29 (in Japanese with English abstract).

Okazaki, Y. (1966) Geology of Kushiro, Kushiro Library 7. pp. 326, Kushiro (in Japanese)

Rollinson, H.R. (1993) Using Geochemical data: evaluation, presentation, interpretation. pp. 352, Longman, Singapore.

Satoh, H. (1965) Explanatory text of the geological map of Japan, scale 1 : 50,000, Akanko. pp. 82, Geological Survey of Japan (in Japanese with English abstract).

Satoh, H. and Sato S. (1976) Explanatory text of the geological map of Japan, scale 1 : 50,000, Tsurui. pp. 24, Geological Survey of Japan (in Japanese with English abstract).

Takahashi, E., Tomiya, A. and Miyagi, I. (1997) Deep structure of island arc volcanoes and its relevance to the generation of silicic arc magma. Bulleten of Volcanological Society of Japan, 42 (Special Isue), 209-218 (in Japanese with English abstract).

Wada, K. (1989) Whole-rock chemical composition of the Akan volcanic field, eastern Hokkaido, Japan: Characterization of magmatism beneath the region. Journal of Hokkaido University of Education (Sec. II B), 39, 37-48.

Manuscript received; 25 September, 2001

Manuscript accepted; 7 January, 2002 